\title{
USE OF COPPER SLAG AS FINE AGGREGATE AND PARTIAL REPLACEMENT OF CEMENT
}

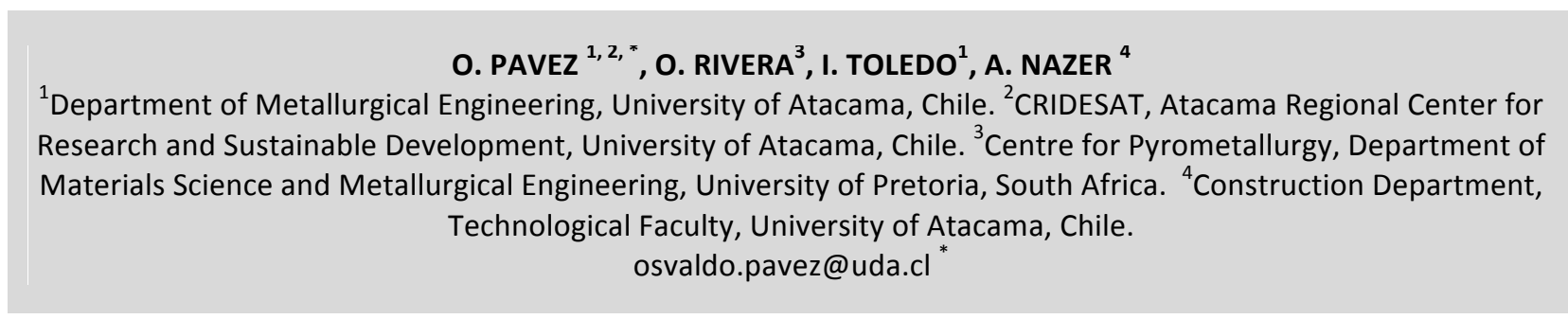

Received 26/12/2017 - Accepted 17/09/2018

DOI: $10.15628 /$ holos.2018.6736

\section{ABSTRACT}

The use of copper slag (CS) as fine aggregate and partial substitute of cement for mortar preparation was studied. Results showed an increase on compressive and flexural strength at 3, 7 and 28 days using CS as fine aggregate. As partial replacement of cement, a gradual improvement on compressive and flexural strength at 7 , 28 and 90 days was noticed. At 7 and 28 days, the control mortar (CM) shows higher compressive strength and
\end{abstract}

flexural strength. Nevertheless, at 90 days, the CM and mortars prepared with CS showed similar compression and flexural strength. The use of CS in the construction industry is hence presented as an auspicious alternative for improving the quality of mortars and mitigating the environmental impacts of slag deposits, adding extra value on this metallurgical waste and reducing the shortage of aggregates of northern Chile.

KEYWORDS: Copper slag, mortar, compressive strength, flexural strength.

\section{USO DE ESCÓRIA DE COBRE COMO AGREGADO FINO E SUBSTITUTO PARCIAL DO CIMENTO}

\section{RESUMO}

Estuda-se o uso de escória de cobre (CS) como agregado fino e substituto parcial do cimento na preparação de argamassas. Os resultados mostraram um aumento na resistência à compressão e à flexão em 3, 7 e 28 dias usando CS como agregado fino. Como substituto parcial do cimento, percebeu-se uma gradual melhoria na resistência à compressão e à flexão no 7, 28 e 90 dias. Em 7 e 28 dias, a argamassa de controle (CM) mostra maior resistência à compressão e resistência à flexão. No entanto, em 90 dias, o CM e as argamassas preparadas com CS mostraram resistência à compressão e resistência à flexão semelhante. $\mathrm{O}$ uso de CS na indústria da construção, portanto, apresenta-se como uma alternativa auspiciosa para melhorar a qualidade de argamassas e mitigar os impactos ambientais dos depósitos de escória, adicionando valor extra ao resíduo metalúrgico e reduzindo a escassez de agregados do norte do Chile.

PALAVRAS-CHAVE: Escória de cobre, argamassa, resistência à compressão, resistência à flexão. 


\section{INTRODUCTION}

Copper minerals are classified as sulfides and oxides. Sulfide minerals are the main source of world's copper ores (about 80\%) and they are commonly found in iron-copper-sulfur compounds such as chalcopyrite $\left(\mathrm{CuFeS}_{2}\right)$, bornite $\left(\mathrm{Cu}_{5} \mathrm{FeS}_{4}\right)$, chalcocite $\left(\mathrm{Cu}_{2} \mathrm{~S}\right)$ and covellite (CuS). These minerals are mainly processed by concentration and pyrometallurgical processing (smelting and refining). Copper oxides (carbonates, oxides, sulfates, hydroxyl-silicates) occur in a lesser extent and they are processed by leaching, solvent extraction and electrowinning (Schlesinger, 2011).

In pyrometallurgy, two immiscible liquid phases are generated: matte and slag. Matte is the copper-rich phase which present a high density, while slag is the low-density and oxide-rich phase. Slag is the discarded material and it is mainly constituted by iron silicates and some oxides like fayalite $\left(\mathrm{Fe}_{2} \mathrm{SiO}_{4}\right)$, magnetite $\left(\mathrm{Fe}_{3} \mathrm{O}_{4}\right)$ and silica $\left(\mathrm{SiO}_{2}\right)$.

From the environmental point of view, the main problem of smelters is the generation of gaseous and solid pollutants, the latter so-called copper slag (CS). The world year production of slag from the copper industry arises to 24.6 Mton, 3.0 Mton generated by the Chilean copper production (Gorai et al., 2003; Valenzuela, 2016). There is thus a need for environmental friendly technologies, in order to mitigate the negative effects of copper smelting.

In Northern Chile, Atacama Region is a mining zone per excellence. Historically, it has been a pillar of economy and at present is one of the largest copper producers regions of Chile. Nowadays in Atacama, there are two currently operating copper smelters: Hernán Videla Lira and Potrerillos; there are also evidences of ancient copper smelters, dating from the XVIII century (Nazer et al. 2016).

Desert areas such as Atacama present low rainfall and therefore a poor renewal of sands and gravel on riverbanks, which translates into a shortage of aggregates for the construction industry. Several studies about the use of CS in construction industry have been developed, results have shown that CS present a high potential for being used like mixing material, due to the increase in mechanical strength (Al-Jabri et al., 2011; Resende et al., 2008; Almeida, 2008; Amaral, 1999).

Considering the above, the main objective of this study was to evaluate the mechanical behavior of mortars using CS as: a) replacement of fine aggregate and b) partial replacement of cement

\section{LITERATURE REVIEW}

The use of CS in construction industry, either as partial or full substitute of cement or aggregate has been reported in the literature (Shi et al. 2008). There are also studies about using CS in cement, mortar and concrete production as raw materials for clinker, cement replacement and coarse/fine aggregates (Tixier et al. 1997; Ariño and Mobasher 1999; Moura et al. 2007; Brindha and Nagan 2010; Nazer et al. 2012; Singh et al. 2014; Saxena 2015). Shi et al. (2008) 
indicated that the use of CS provides environmental and economic benefits for all related industries, especially in areas where considerable amounts of CS are generated.

Brindha and Nagan (2010) evaluated the effect of replacing fine aggregate by CS in concrete mixes. They reported an optimal sand replacement by CS of $40 \mathrm{wt} \%$, which increased concrete density by $7 \%$ and both compressive and split tensile strength by 34.88 and $92.30 \%$, respectively. Singh et al. (2014) studied the effect of partial replacement of fine aggregates by CS, they found that for all evaluated setting times, compressive and flexural strength were higher or similar to control concrete. Madheswaran et al. (2014) studied the use of CS in building construction as partial replacement of sand in cement concrete. They reported an increase on density, workability and compressive strength with CS additions of 50 wt\% for conventional concrete, and $75 \%$ for high strength concrete. Singh and Bath (2015) studied the effect of replacing natural aggregates by CS in flexural strength of concrete at 7 and 28 days, results showed an increase of flexural strength as CS increased up to 40\%. Mavrodilou and Liya (2015) carried out a study using water-cooled CS in concrete mixes at 7 and 28 days and water/cement $(\mathrm{w} / \mathrm{c})$ ratios of 0.55 and 0.45 . They showed that workability, compressive and tensile strength values of mixes with CS addition were slight lower but comparable to control mix. A research about strength and durability of concrete using 10, 20, 30 and 40 wt\% of CS in replacement of fine aggregate, showed that the addition of CS increases the strength of concrete (Leema and Suganya, 2015). Srinivas and Muranal (2015) carried out an experimental study on concrete with CS as partial replacement of sand; they showed that workability increases with the CS content, and compressive strength increases up to $8.63 \%$ when $20 \mathrm{wt} \%$ CS is added.

Some researchers have investigated the use of CS as partial replacement of Portland cement (PC). Zain et al. (2004) reported that the addition of CS to cement increased initial and final setting time, but strength of CS mortar was generally lower than the control mortar (CM); the highest strength was achieved using $5 \%$ of CS as cement replacing. Orizola (2006) studied the behavior of hydraulic cement mortars with CS as replacement of PC, according to NCh 148 Of 68 . The addition of $25 \%$ CS increased mechanical strength for both ordinary and high-strength cement, while an addition of $40 \%$ CS increased mechanical strength of ordinary cement. Moura et al. (2007) reported a potential use of CS as supplementary cementing material for concrete production. They also indicated that concrete batches with $20 \%$ of CS presented greater mechanical properties and durability performance.

Sánchez de Rojas et al. (2008) indicated that replacement of $30 \%$ cement by CS reduces flexural and compressive strength in a similar way to fly ash, but after 28 days the reduction is less than the percentage of substitution. They reported that pozzolanic activity of CS is similar to fly ash and higher than silica fume. A study about mortars using cement and CS reported that compressive strength of CS mortars is lower at early stages but at 28 days the results are reversed, concluding that CS provides a delaying effect in the strengthening process (Alp et al. 2008). Najimi et al. (2011) ranged CS replacement from 0 to $15 \%$ and samples were immersed in $\mathrm{Na}_{2} \mathrm{SO}_{4}$ solution for 120 days. Concrete with CS showed greater sulfate attack resistance, while compressive strength decreased when CS amount under normal conditions was increased. Singh et al. (2014b) reported that $\mathrm{CS}$ can be used as supplementary cement replacement in concrete, with an optimum CS amount of $10 \%$. Nazer et al. (2016) studied pozzolanic behavior of Chilean smelters CS 
on PC mortars using $25 \% \mathrm{CS}$; they also studied the pozzolanic reactivity of alkali activated mortars cured at 20 and $65 \stackrel{\circ}{ }$; ; results showed that CS has cementing properties.

\section{MATERIALS AND METHODS}

CS was collected from Hernán Videla Lira Smelter (HVL-CS). It was processed by jaw and cone crushing ( 5 and $3 \mathrm{~mm}$ setting, respectively) for its use as fine aggregate, with an additional stage of disk milling (100\% under 400 \# Tyler) for CS as cement replacement. High Strength Portland Cement (HSPC) was used with HVL-CS according to NCh 148 Of 68. Sand river and drinking water were used in all tests.

\subsection{Characterization of HVL-CS and sand}

Chemical characterization of HVL-CS was performed by Atomic Absorption and Volumetric Analysis. Mineralogical characterization of HVL-CS was carried out by X-ray diffraction (XRD) in a SIEMENS SRS 3000 ( $\mathrm{Cu} \mathrm{K \alpha}$ ) diffractometer. X-ray Fluorescence (XRF) was used for chemical analysis of cement, using lithium tetraborate melting method (PANalytical Axios mAX-XRF spectrometer). Particle size distribution (PSD) of CS as fine aggregate was determined by conventional sieving, laser diffraction (Malvern Mastersizer 2000 particle size analyzer) for PSD of CS used as partial replacement of cement. Morphology of CS as partial replacement of cement was analyzed in a Zeiss EVO MA 10 scanning electron microscope. HVL-CS and sand were also characterized by: apparent and bulk density (NCh 1116 Of 77 and NCh 1239 Of 77, respectively); fine material under $0.080 \mathrm{~mm}$ (NCh 1223 Of 77); light material present in aggregate (coal and lignite, ASTM C 123); organic impurities in sand (NCh 166 Of 2009); chlorides and sulfates content (NCh 1444 Of 2010) and disintegration by sulfates method (NCh 1444 Of 2010).

\subsection{Fabrication of mortars using HVL-CS as fine aggregate}

PSD of HVL-CS and sand were adjusted under NCh 163 Of 79 and NCh 165 Of 2009. Control factor for mortars with CS and sand was the normal consistency according to NCh 2257/1 Of 96; $\mathrm{w} / \mathrm{c}$ ratio was determined based on this test. Specimens of $40 \times 40 \times 160 \mathrm{~mm}$ and curing times of 3, 7 and 28 days were considered for mechanical testing. Setting time was determined in order to verify the CS influence in mortar hardening, according to NCh 2183 Of 92. Penetrometer was used to determine initial and final setting time, according to NCh 2183 Of 92. Compressive and flexural strength tests were carried out according to NCh 2261 Of 96. Before mechanical testing, mortars were compacted on a vibratory table, then flushed and sent to moisture chambers for 24 hours. Finally, mortars were demolded and immersed in a lime-saturated water solution until their rupture at 3, 7 and 28 days. Compressive strength was determined using the specimens used on flexural tests. Table 1 shows the parameters of mortars used in this study. 
Table 1. Formulation of mortars using CS as fine aggregate

\begin{tabular}{c|c|c|c|c|c}
\hline Material & Aggregate $(\mathrm{g})$ & Cement $(\mathrm{g})$ & $\begin{array}{c}\text { Normal consistency } \\
(\mathrm{mm})\end{array}$ & $\begin{array}{c}\text { w/c } \\
\text { ratio }\end{array}$ & $\begin{array}{c}\text { Cement/aggregate } \\
\text { ratio }\end{array}$ \\
\hline HVL-CS & 2350 & 783 & $211 \pm 5$ & 0.44 & $1: 3$ \\
Sand & 1500 & 517 & $210 \pm 5$ & 0.53 & $1: 3$ \\
\hline
\end{tabular}

\subsection{Fabrication of mortars using HVL-CS as partial replacement of cement}

HVL-CS was sieved in a 4\# Tyler mesh, the oversize was discarded and the undersize grinded in a disk mill, in order to comply with pozzolana properties according to NCh 161 Of 69. PSD of HVL-CS and sand were adjusted to fulfill NCh 163 Of 79 and NCh 165 Of 2009. Design parameters for compressive and flexural tests under NCh 158 of 67 are presented on Table 2 .

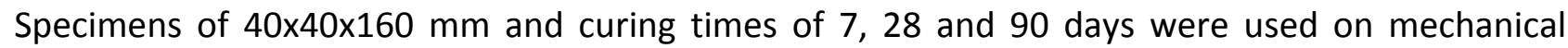
testing. For curing, samples were submerged on water and lime-saturated water, according to NCh 2261 Of 2010. Tests were performed with 0\% CS for the CM and 5, 10, 15 and 20\% of HVL-CS as partial replacement of HSPC.

Table 2. Formulation of mortars using CS as partial replacement of cement

\begin{tabular}{c|c|c|c|c|c}
\hline $\begin{array}{c}\text { CS content } \\
\text { (wt \%) }\end{array}$ & $\begin{array}{c}\text { Curing time } \\
\text { (days) }\end{array}$ & Cement (g) & HVL-CS (g) & Sand (g) & Water (g) \\
\hline 0 & 7,28 and 90 & 450.0 & 0.0 & 1350 & 240 \\
5 & 7,28 and 90 & 427.5 & 22.5 & 1350 & 240 \\
10 & 7,28 and 90 & 405.0 & 45.0 & 1350 & 240 \\
15 & 7,28 and 90 & 382.5 & 67.5 & 1350 & 240 \\
20 & 7,28 and 90 & 360 & 90.0 & 1350 & 240 \\
\hline
\end{tabular}

\section{RESULTS AND DISCUSSION}

\subsection{Characterization and experimental results}

Mineralogical analysis of HVL-CS showed the following compounds: hedenbergite $(23.90 \%)$, magnetite $(20.36 \%)$, fayalite $(20.00 \%)$, albite(18.05\%), phengite $(9.55 \%)$, quartz $(2.01 \%)$, pseudochalcopyrite $(0.93 \%)$, hematite $(0.76 \%)$, pseudo-bornite $(0.14 \%)$, pseudo-pyrite $(0.14 \%)$, native copper $(0.08 \%)$, limonite $(0.08 \%)$, pseudo-chalcocite $(0.05 \%)$ and other compounds (3.95\%). High concentration of iron and silica from main compounds like hedenbergite, magnetite, fayalite and phengite is verified. It was estimated some potentiality for pozzolana production. Table 3 shows the chemical analysis of cement. 
Table 3. Chemical analysis of cement

\begin{tabular}{l|l|l|l|l|l|l|l|l|l|l|l|l|l}
\hline Oxide & $\mathrm{CaO}$ & $\mathrm{SiO}_{2}$ & $\mathrm{Al}_{2} \mathrm{O}_{3}$ & $\mathrm{Fe}_{2} \mathrm{O}_{3}$ & $\mathrm{SO}_{3}$ & $\mathrm{MgO}$ & $\mathrm{TiO}_{2}$ & $\mathrm{Na}_{2} \mathrm{O}$ & $\mathrm{K}_{2} \mathrm{O}$ & $\mathrm{MnO}$ & $\mathrm{P}_{2} \mathrm{O}_{5}$ & $\mathrm{SrO}$ & $\mathrm{BaO}$ \\
\hline$\%$ & 64.99 & 19.40 & 5.12 & 3.32 & 3.00 & 0.86 & 0.28 & 0.23 & 0.22 & 0.08 & 0.06 & 0.04 & 0.01 \\
\hline
\end{tabular}

Figure 1 shows the PSD of sand, HVL-CS and NCh 2256/1 Of 2001. Botch HVL-CS and sand PSD complies with the standard.

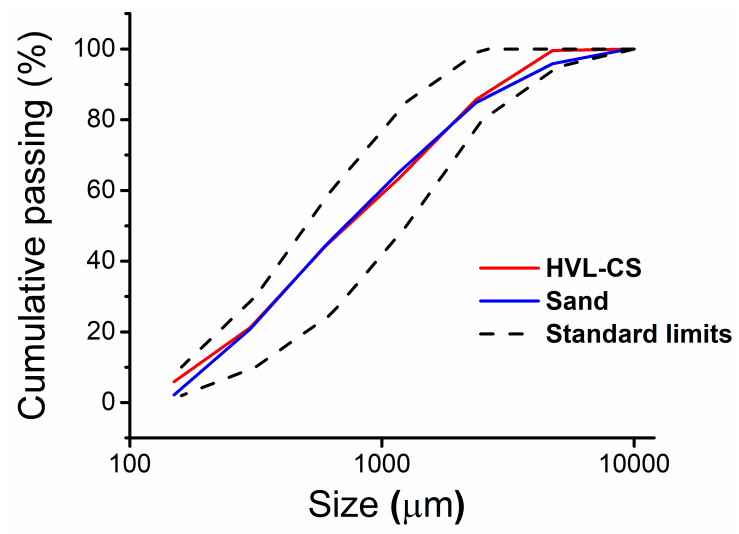

Figure 1. PSD of HVL-CS, sand and NCh 2256/1 Of 2001.

PSD of cement and HVL-CS as cement replacement are shown in Figure 2. HVL-CS presented a $90 \%$ of particles smaller than $25.81 \mu \mathrm{m}$ and $50 \%$ smaller than $7.90 \mu \mathrm{m}$. In case of cement, $90 \%$ of particles are smaller than $48.69 \mu \mathrm{m}$ and $50 \%$ smaller than $17.64 \mu \mathrm{m}$. Measured specific surface area were 1.28 and $0.70 \mathrm{~m}^{2} / \mathrm{g}$ for HVL-CS and cement, respectively.

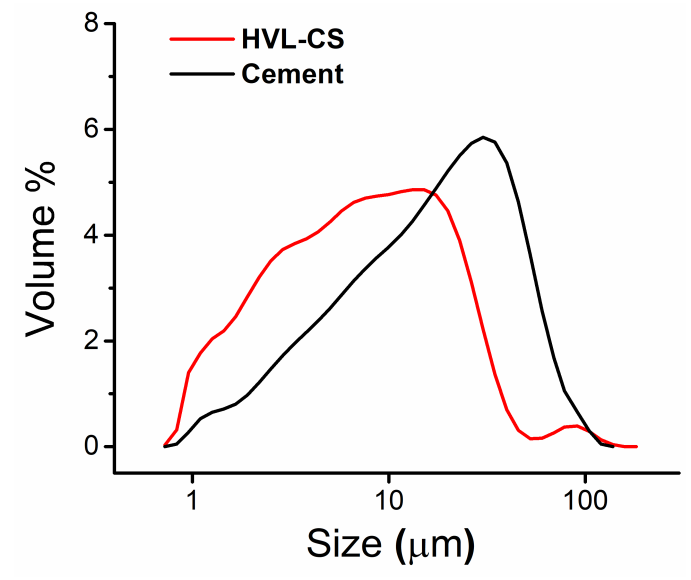

Figure 2. PSD of cement and HVL-CS used as HSPC replacement.

A SEM image of HVL-CS used as replacement of HSPC is presented in Figure 3. Particles show a spread size distribution and irregular morphology. A previous study about CS from Hernán Videla Lira Smelter done by Rojas (2004), reported that HVL-CS presents the following types of surface: cavernous-smooth, cavernous-smooth-rough and smooth-rough. Results showed the 
highest increase in the resistance of concrete when using cavernous CS, as the cement paste can penetrate the cavities improving adhesion and strength.

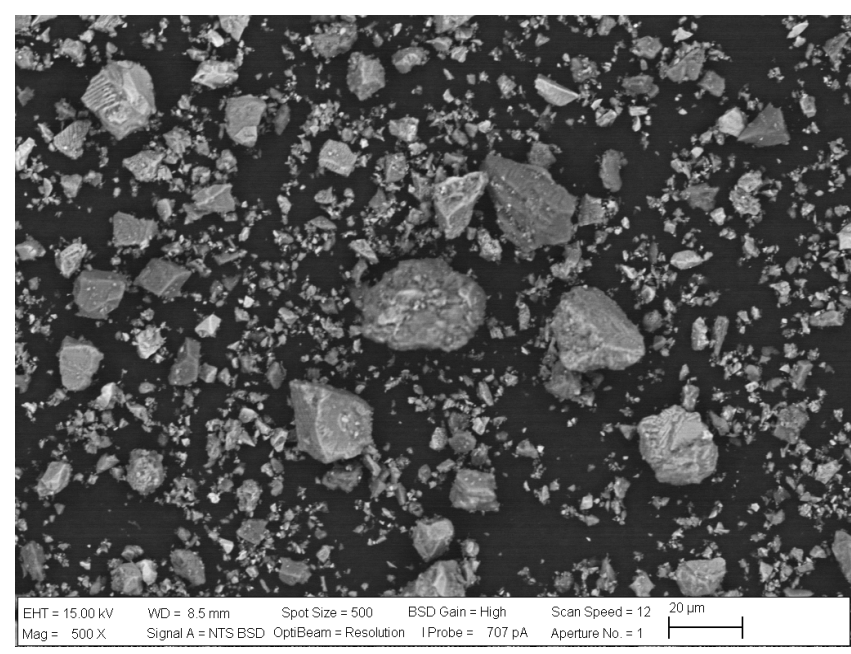

Figure 3. SEM image of HVL-CS used HSPC replacement.

Table 4 show the main properties of HVL-CS and sand. Results show that HVL-CS presents better properties than sand: HVL-CS density is $32 \%$ higher and showed lower water absorption, which implies improved performance and lower porosity. In addition, HVL-CS presents lower chlorides and sulfates content (NCh 1444 Of 2010 and NCh 163 Of 79) and greater response to sodium sulfate disintegration. Both HVL-CS and sand meet all the rest of standards (e.g. particles < $0.080 \mathrm{~mm}$ : NCh 163 Of 79 and NCh 1223 Of 77).

Table 3. Main properties of HVL-CS and sand

\begin{tabular}{|c|c|c|}
\hline Technical parameter & HVL-CS & Sand \\
\hline Apparent density $(\mathrm{kg} / \mathrm{m} 3)$ & 2.455 & 1.714 \\
\hline Real density (kg/m3) & 3.857 & 2.547 \\
\hline Water absorption(\%) & 0.72 & 2.21 \\
\hline Fineness modulus & 2.78 & 2.73 \\
\hline Particles $<0,080 \mathrm{~mm}(\%)$ & 2.34 & 2.69 \\
\hline Presence of coal and lignite (\%) & 0.0 & 0.0 \\
\hline Presence of organic impurities & Not detected & Minimum \\
\hline Content of chlorides (Cl-) (kg/m3) & 0.01 & 0.08 \\
\hline Content of sulfates (SO4-2) (kg/m3) & 0.04 & 0.28 \\
\hline Disintegration by sodium sulfate (\%) & 0.1 & 0.6 \\
\hline
\end{tabular}




\subsubsection{Mortars with HVL-CS as fine aggregate}

Initial and final setting time were 304 and 568 min for HVL-CS mortars and 362 and 588 min for the CM. HVL-CS mortars show a notorious difference of about $20 \%$ on initial time, but slight at final setting time. This could be beneficial when higher resistance is required in short time.

Figures 4.a and 4.b show the increase on compressive and flexural strength after 3, 7 and 28 days, for mortars using HVL-CS as replacement of sand. As time increases, the difference between compressive strength of HVL-CS and the CM decreases from $43.5 \%$ to $28.7 \%$ and $18.4 \%$ after 3,7 and 28 days, respectively. Similar flexural strength at 3 and 7 days (39.6 and 40.6\%, respectively) was verified, decreasing to $33.8 \%$ after 28 days.

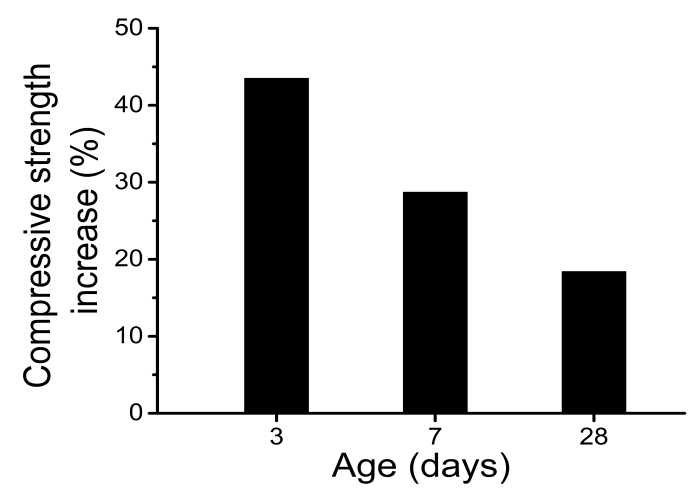

a)

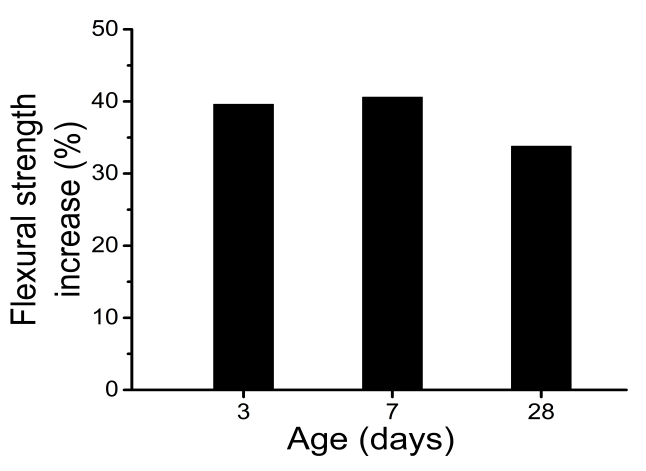

b)

Figure 4. Effect of sand replacement by HVL-CS after 3, 7 and 28 days on increase of a) compressive strength b) flexural strength.

\subsubsection{Mortars with HVL-CS as partial replacement of cement}

Figures 5.a and 5.b show the compressive strength of the $\mathrm{CM}$ and mortars with partial replacement of cement. As time increases, the compressive strength of all mortars increases. There is also a notorious variation between compressive strength of the $\mathrm{CM}$ and mortars with cement replacement. A decrease in the difference of the resistances between mortars with replacement of cement and the $\mathrm{CM}$ is noticed as time increases. At 7 days we found the greatest difference between the CM and HVL-CS mortar, the difference was observed in mortar with $10 \%$ CS and the compressive strength is $37 \%$ lower than the CM. At the same age, mortars with $5 \%$, $15 \%$ and $20 \%$ of CS showed a lower difference with the CM (23\%, 30\% and $23 \%$ respectively). As the age increased to 28 and 90 days, the difference on compressive strength decreased. At 28 days, all mortars with cement substitution showed lower resistance than the $\mathrm{CM}$, with a maximum difference of only $9 \%$ for mortar with $15 \%$ of cement substitution. At 90 days values are similar, and even mortars with $15 \%$ and $20 \%$ of cement replacement, values obtained are slightly higher than the $\mathrm{CM}$. 
40

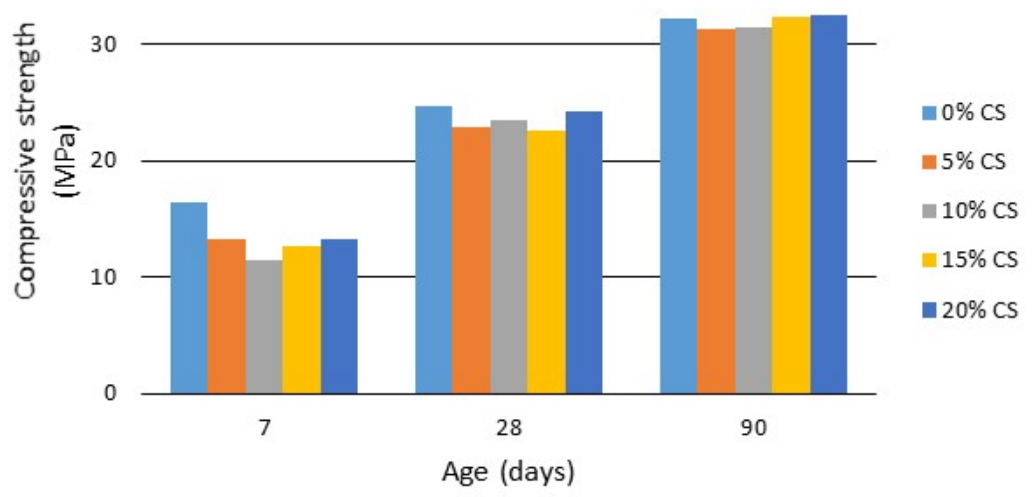

Figure 5. Compressive strength of the CM and mortars with HVL-CS as partial replacement of cement as function of age.

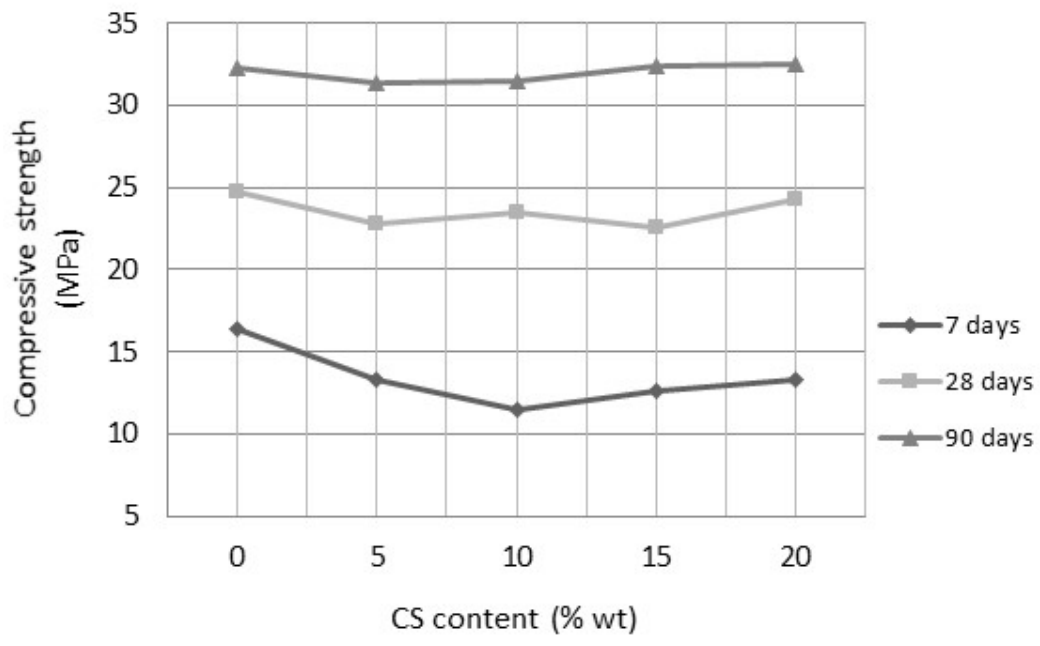

Figure 6. Compressive strength of the CM and mortars with HVL-CS as partial replacement of cement as function of CS content.

Figures 7 and 8 show the flexural strength of the CM and HVL-CS mortars. It is observed that as age increases, flexural strength increases for all mortars. It is also seen that the difference between flexural strength of the $\mathrm{CM}$ and the cement substituted mortars decreases with time. The greatest difference between the the CM and HVL-CS mortars was observed at 7 and 28 days. At 7 days, a maximum difference was observed in the $10 \%$ CS mortar, flexural strength was $38 \%$ lower than the CM. At the same age, mortars with 5, 15 and $20 \%$ of CS also presented lower resistance than the CM, but the difference was lower: $29 \%, 31 \%$ and $21 \%$ respectively. At 28 days, flexural strength of mortars with 15 and $20 \%$ CS was $37 \%$ and $33 \%$ lower than the CM, respectively. At the same age, differences decrease to $11 \%$ and $9 \%$ in mortars prepared with $5 \%$ and $10 \%$ of CS, respectively. At 90 days, the difference between flexural strength is minimal and mortars with 5 and $10 \%$ CS showed higher values than the CM. At 90 days, for mortars with 15 and $20 \%$ of CS, flexural strength is similar to the CM. However, mortars with 5 and $10 \%$ of CS presented higher values: $9 \%$ and $8 \%$, respectively. 


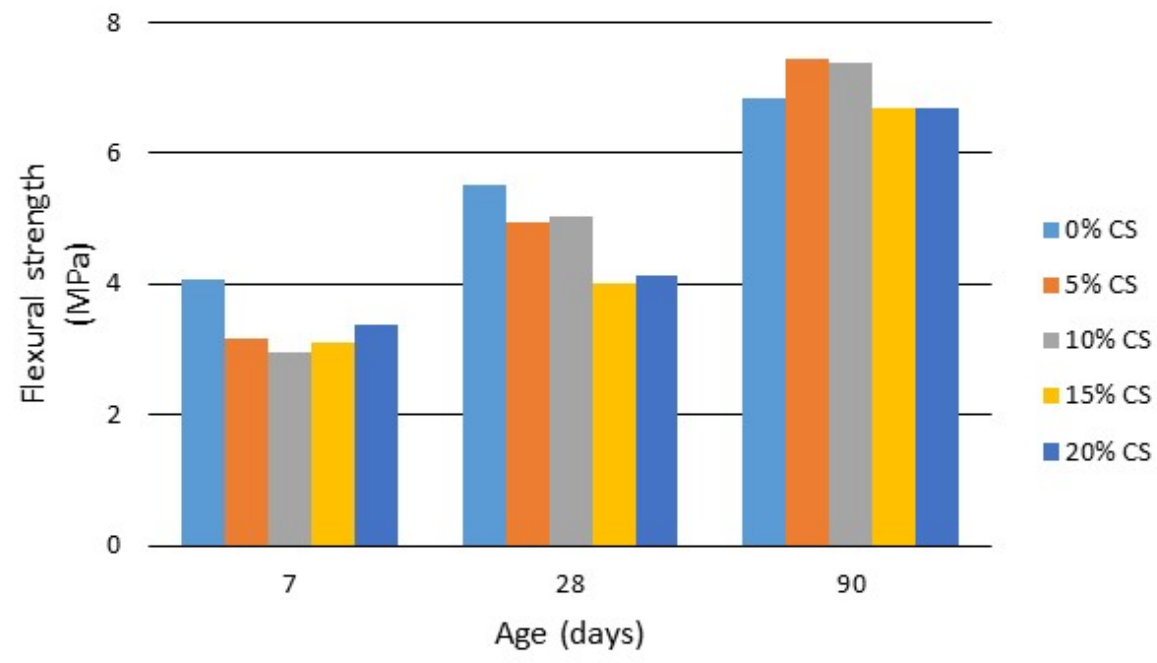

Figure 7. Flexural strength of the CM and mortars with HVL-CS as partial replacement of cement as function of age.

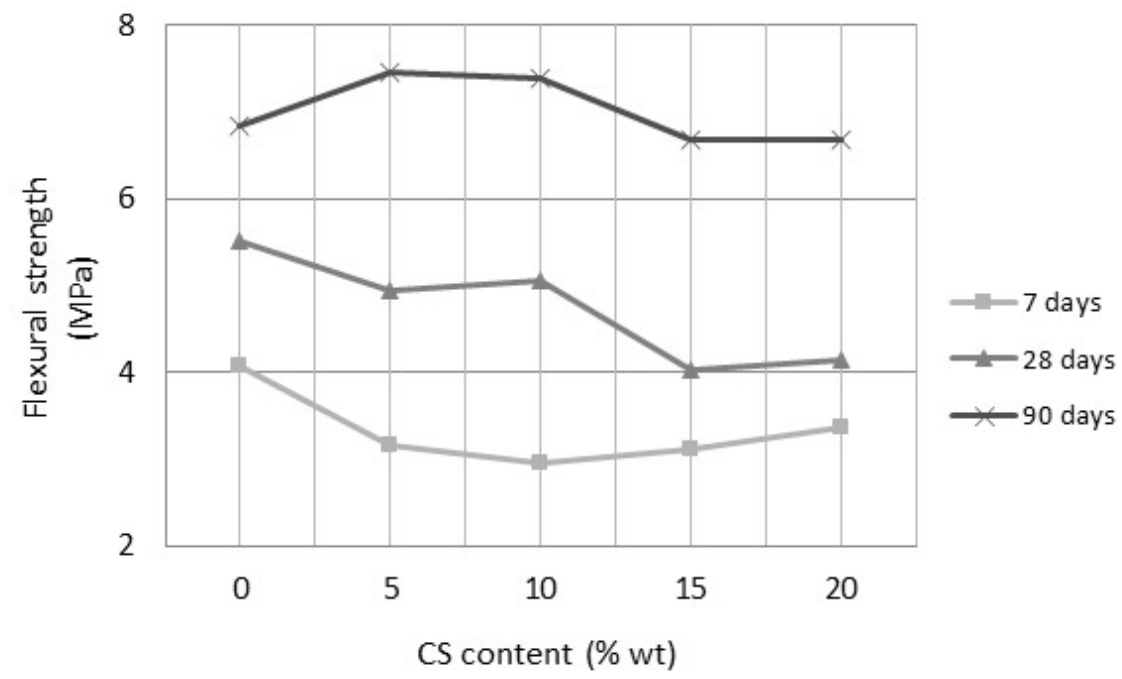

Figure 7. Flexural strength of the CM and mortars with HVL-CS as partial replacement of cement as function of CS content.

According to Figures $6,7,8$ and 9, at 90 days the highest values of compression resistance were obtained by 15 and $20 \%$ CS replacement, while mortars with 5 and $10 \%$ CS showed the best results in terms of flexural strength.

\subsection{Discussion of results}

Results of mechanical tests showed the increase in compressive and flexural strength at 3, 7 and 28 days for mortars using CS replacing sand. The increase in compression strength is greater at 3 days, this difference decreases as time increases. On the other hand, the increase in flexural strength is similar at 3 and 7 days, decreasing this difference at 28 days. These results indicate show that HVL-CS presence in mortars increases mechanical strength, in comparison to mortars prepared with sand. 
The increase on mechanical strength when sand is partially or totally replaced by $\mathrm{CS}$, is reported in literature. Singh et al. (2014a) reported 28 days as maximum increase on compressive and flexural strength of 54.87 and $26.62 \%$ for mortars using 40 and $30 \%$ of CS, respectively. Leema and Suganya (2015) verified at 28 days a $45.42 \%$ of increase in compressive strength if $30 \%$ of CS were added to mixture. Amarnaath et al. (2015) reported an optimal value of $35 \%$ of CS to produce mortars with high strength and improved properties. They also identified the lowest compressive strength of about $16 \%$ lower than the CM, when $100 \%$ of CS is used. Flexural strength was evaluated by Singh and Bath (2015) at 0, 20, 40, 60, 80 and 100\% of CS, at 7 and 28 days of curing time. Results showed an increase of $17 \%$ on flexural strength with $40 \%$ of CS; these results oppose with the present study, where $100 \%$ of CS as fine aggregate increases the compressive strength. Mavroulidou and Liya (2015) indicated that an appropriate selection of w/c ratio allow to successfully replace sand by CS in concrete.

Mechanical tests showed a gradual increase on compressive and flexural strength at 7, 28 and 90 days in mortars with HVL-CS as cement replacement. At 7 and 28 days, the CM presented a higher compressive strength; this difference is more noticeable at 7 days. At 90 days, all mortars showed similar values on compressive strength and mortars with 15 and $20 \%$ CS showed higher values than the CM. At 7 and 28 days, the CM presented higher flexural strength, however, this difference becomes minimal at 90 days, mortars with 5 and $10 \%$ CS showed higher strength than the CM. Orizola (2006), Alp et al. (2008) and Mobasher et al., (1996), also reported similar early decrease at 7 days in compressive and flexural strength by addition of CS.

The increase on mechanical strength by replacing cement with CS has been reported by several studies. Moura et al. (2007) used $20 \%$ of CS replacing PC and w/c ratios of $0.4,0.5$ and 0.6. They reported that at 28 days, all samples increased their compressive strength up to $30.4 \%$ (w/c=0.6). Pradeep and Kumar (2013) reported an increase up to $19 \%$ on compressive and flexural strength and $32 \%$ on split tensile strength, when $16 \%$ of CS was used as partial replacement of cement. Mobasher et al (1996) noted that most of strength increase takes place between 28 and 90 days. They suggested that at longer times and due to cement hydration, there is a gradual increase of $\mathrm{Ca}(\mathrm{OH})_{2}$ which reacts with pozzolana, producing cementitious material. Mobasher et al. (1997) studied the effect of CS on hydration and mechanical properties of cement-based mixtures. They indicate that the slag-cement mixture shows a noticeable increase in compressive strength in the concrete mixture. This increase was attributed to: a) microstructure densification in capillary pores, b) reduction in capillary porosity of slag grains and c) pozzolanic activity. Rojas (2004) evaluated the pozzolanic effect of the HVL-CS in presence of $\mathrm{Ca}(\mathrm{OH})_{2}$, indicating that CS provides resistance to the mixture and that the finely divided CS has cementing properties. Rojas used a $95 \%(<75 \mu \mathrm{m}) \mathrm{HVL}-\mathrm{CS}$ paste with $5 \mathrm{wt} \%$ hydrated lime of normal consistency, cured in a humid chamber up to the test ages of 1 hour, 13 days and 58 days. XRD results showed a decrease on available Portlandlite $\left(\mathrm{Ca}(\mathrm{OH})_{2}\right)$ in the lime-slag sample, which it was attributed to the formation of hydration products.

Several studies have reported a decrease on mechanical strength when using CS as cement replacement. Singh et al. (2014b) indicated that compressive strength of concrete decreases as CS increases for all the studied curing times, reporting $10 \%$ of CS as optimum. Sánchez de Rojas et al. (2008) indicated that a replacement of cement by $30 \%$ CS reduces both flexural and compressive strength in a similar way to fly ash, but after 28 days the reduction is less than the substitution 
percentage. Zain et al. (2004) ranged CS content from 0 to $10 \%$. They analyzed leachability, compressive strength and hydration of crushed and non-crushed samples. CS mortars generally showed lower strength and the optimum CS content was about $5 \%$. Orizola (2006) reported a decrease in mechanical strength when 25 and $40 \%$ of PC is replaced by CS.

\section{CONCLUSIONS}

Results show that the high density of HVL-CS in comparison to sand is related to the high level of Fe-oxides and Fe-silicates found by XRD. Also, HVL-CS comply with all the standards required from construction industry.

Mechanical testing showed an increase in compressive and flexural strength at 3, 7 and 28 days for mortars with CS replacement of sand. The highest increase in compression strength was noticed at 3 days, decreasing this value as time increased. The increase in flexural strength is similar at 3 and 7 days, but the increase is lower at 28 days. HVL-CS mortars also presented lower initial setting time, which could be advantageous when high resistance is needed in early stages. HVL-CS also showed better properties than sand, as water absorption, chlorides/sulfates content and sodium sulfate disintegration, which makes it a suitable candidate for sand replacement.

When using CS as partial replacement of cement, a gradual increase on compressive and flexural strength at 7, 28 and 90 days was noticed. At 7 and 28 days, the CM presented higher compressive and flexural strength, the difference is higher at 7 days for compressive strength and 28 days for flexural strength. At 90 days, HVL-CS mortars and the CM showed similar compression and flexural strength, compressive strength of HVL-CS mortars was slightly higher than the CM, while in mortars with 5 and $10 \%$ of CS, the obtained flexural strength was higher that the CM by $9 \%$ and $8 \%$, respectively.

Results indicate that the use of CS in construction industry is presented as an auspicious alternative not only for improving the quality of mortars, but also to mitigate the adverse effects of copper mining in the environmental and reducing the shortage of aggregates that exists in Atacama.

\section{ACKNOWLEDGEMENTS}

The authors thank Hernán Videla Lira Smelter and INACESA Company. Dr. Pavez gratefully acknowledges to the Vice-Rectory of Research and Graduate Studies of Universidad de Atacama for financial support of Project DIUDA 22299. Also, the authors wish to thank Miss Evelyn Cárdenas from Metallurgical Engineering Department of Universidad de Atacama, for her assistance in reviewing this paper.

\section{REFERENCES}

Al-Jabri, K.S., Al-Saidy, A.H, Taha, R. (2011). Effect of copper slag as a fine aggregate on the properties of cement mortars and concrete. Constr. Build. Mater. 25 (2), 933-938, DOI: https://doi.org/10.1016/j.conbuildmat.2010.06.090. 
Almeida, M., (2000). Utilizaçao de escória de cobre como adiçao e como agregado miúdo para concreto. Ph.D. thesis, Universidade Federal do Rio Grande do Sul (in Portuguese).

Alp, I., Deveci, H., Süngün, H. (2008). Utilization of flotation wastes of copper slag as raw material in cement production. J. of Haz. Mat., ELSEVIER, 159, 390-395, DOI: 10.1016/j.jhazmat.2008.02.056

Amarnaath, M.R., Pradeep, S.J., Kavin, R.A., Dinesh, P., Hari-baskaran, S. (2015) A study on effective replacement of fine aggregate using copper slag. Int. J. Sci. Tech. Eng. 1 (10), 227231.

Amaral, L., (1999). Hormigones con escoria de horno eléctrico como áridos: propiedades, durabilidad y comportamiento ambiental. Ph.D. thesis, Universidad Técnica de Catalunya.

Ariño, A.M., Mobasher, B., (1999). Effect of ground copper slag on strength and toughness of cementitious mixes. ACI Mater. J. 96 (1), 68-73.

Brindha, D., Nagan, S., (2010). Utilization of copper slag as a partial replacement of fine aggregate in concrete. Int. J. Earth Sci. Eng. 03 (4), 579-585.

Gorai, B., Jana, R.K, Premchand, (2003). Characteristics and utilization of copper slag - A review. Resour. Conserv. Recy. 39, 299-313, DOI: 10.1016/S0921-3449(02)00171-4.

Leema, A., Suganya, P., (2015). Performance of copper slag on strength and durability properties as partial replacement of fine aggregate in concrete. IJETAE. 5 (1), 434-437.

Madheswaran, C.K., Ambily, P.S., Dattatreya, J.K., Rajamane, N.P., (2014). Studies on use of copper slag as replacement material for river sand in building constructions. J. Inst. Eng. (India): Ser. A. 95 (3), 169-177, DOI: 10.1007/s40030-014-0084-9.

Mavroulidou, M., Liya, N., (2015). Properties of concrete containing waste copper slag as a fine aggregate replacement. Proceedings of the 14th International Conference on Environmental Science and Technology, September 3-5, 2015, Rhodes, Greece.

Mobasher, B., Devaguptapu, R., Arino, A.M., (1996). Effect of copper slag on the hydration of blended cementitious mixtures. Proceedings of the ASCE Materials Engineering Conference. 2 1677-1686.

Mobasher B., Tixier R., Devaguptapu R., (1997). The effect of copper slag on the hydration and mechanical properties of cementitious mixtures. Cement and Concrete Research. 27 (10), 1569-1580, DOI: 10.1016/S0008-8846(97)00166-X.

Moura, W.A., Gonçalves, J.P., Lima, M.B.L., (2007). Copper slag waste as a supplementary cementing material to concrete. J. Mater. Sci. 42 (7), 2226-2230, DOI: 10.1007/s10853-0060997-4 
Najimi, M., Sobhani, J., Pourkhorshidi, A.R., (2011). Durability of copper slag contained concrete exposed to sulphate attack. Constr. Build. Mater. 25 (4) 1895-1905, DOI: 10.1016/j.conbuildmat.2010.11.067

Nazer A., Payá J., Borrachero M. V., Monzó J., (2016). Use of ancient copper slags in Portland cement and alkali activated cement matrices. J. Environ. Manage. 167, 115-123. DOI: 0.1016/j.jenvman.2015.11.024.

Nazer, A., Pavez, O., Rojas, F., (2012). Use of copper slag in cement mortar. REM-Rev. Esc. Minas. 65 (1), 87-91, DOI: 10.1590/S0370-44672012000100012.

Orizola, S., (2006). Uso de escorias de cobre en cementos. Civil Engineering Thesis, Universidad de Chile (in Spanish).

Pradeep, V., Kumar, K., (2013). The behavior of concrete in terms of flexural, tensile \& compressive strength properties by using copper slag as an admixture. Int. J. Eng. Innov. Tech. 3 (4), 462465.

Resende, C., Cachim, P.B., Bastos, A.M., (2008). Copper Slag Mortar Properties. Mat. Sci. For. 587588, 862-866, DOI: 10.4028/www.scientific.net/MSF.587-588.862.

Rojas, F., (2004). Prefactibilidad técnica del uso de la escoria de cobre en morteros y hormigones. Metallurgical Engineering Thesis, Universidad de Atacama, 171 pp. (in Spanish).

Sánchez de Rojas, M.I., Rivera, J., Frías, M., Marín, F., (2008). Use of recycled copper slag for blended cements. J. Chem. Tech. Biot. 83 (3), 209-217, DOI: DOI: 10.1002/jctb.1830.

Saxena, P. (2015) Experimental study on mechanical properties of M30 concrete with partial replacement of cement and fine aggregate with silica fume and copper slag. Int. J. Res. Eng. Tech. 4 (5), 283-286.

Shi, C., Meyer, C., Behnood, A., (2008). Utilization of copper slag in cement and concrete. Resour. Conserv. Recy. 52, 115-1120, DOI: 0.1016/j.resconrec.2008.06.008.

Singh, H.; Bath, G. (2015) Use of copper slag as fine aggregate - A case study. Int. J. Innov. Res. Sci. Eng. 2 (5).

Singh, T., Rajashekhara, M.R., Suhas, R., (2014a). Utilization of copper slag as fine aggregates in cement concrete pavements. Int. J. Res. Eng. Tech. 2 (7), 358-365.

Singh, J., Singh, J., Kaur, M. (2014b) Use of copper slag in concrete. Int. J. Adv. Res. Eng. Appl. Sci. 3 (12).

Srinivas, C.H., Muranal, S.M.. (2015). Study of the properties of concrete containing copper slag as a fine aggregate. Int. J. Eng. Res. Tech. 4 (2). 
Tixier, R., Devaguptapu, R., Mobasher, B., (1997). The effect of copper slag on the hydration and mechanical properties of cementitious mixtures. Cem. Concr. Res. 27 (10), 1569-1580.

Toledo, I., (2012). Efecto de las escorias de cobre como agregado fino en la resistencia de morteros de cemento. Metallurgical Engineering Thesis, Universidad de Atacama, 141 pp. (in Spanish).

Valenzuela, A., (2016). Mining waste management in Chile: Experience, challenges and opportunities. Workshop on best practices on mining policies and technologies. Thematic session 2: Mining waste management and mine rehabilitation. 14th International EXPOMIN Congress. April 25-29, 2016, Santiago, Chile.

Zain, M.F.M., Islam, M.N., Radin, S.S., Yap, S.G., (2004). Cement-based solidification for the safe disposal of blasted copper slag. Cem. Concr. Compos. 26 (7), 845-851, DOI: 10.1016/j.cemconcomp.2003.08.002. 